ство реагирующих веществ в калориметре составляло 200-300 мл. Термометрическая чувствительность установки равнялась $0,0009-0,004$ град/мм шкалы прибора, тепловое значение - 9720 дж/град. Погрешность измерения в случае тепловых эффектов реакции выше $5 \cdot 10^{3} \partial \varkappa$ остается в пределах $\pm 1 \%$.

$\begin{array}{cc}\text { Институт химии } & \text { Поступила в редакцию } \\ \text { Академии наук Эстонской ССР } & 30 / \text { ХII } 1971\end{array}$

EESTI NSV TEADUSTE AKADEEMIA TOIMETISED, 21. KOIDE KEEMIA * GEOLOOGIA. 1972, NR. 3

ИЗВЕСТИЯ АКАДЕМИИ НАУК ЭСТОНСКОП ССР. ТОМ 21 ХИМИЯ * ГЕОЛ.ГИЯ. і972, N. 3

удК $551.732 .2(474.2)$

Э. КАЛА

\title{
О ВОЗРАСТЕ ТИСКРЕСКИХ СЛОЕВ ПО МАТЕРИАЛАМ ОСТРОВА ХИИУМАА
}

E. KALA. TISKRE KIHTIDE VANUSEST HIIUMAA MATERJALIDE ALUSEL

E. KALA. ON THE AGE OF THE TISKRE BEDS IN THE ISLE OF HIIUMAA

При геологическом картировании территории о. Хийумаа автором по четырем буровым скважинам были детально изучены нижнекембрийские отложения, представляющие здесь особый интерес для определения возраста тискреских слоев и установления на территории Эстонии вышележащих курземских слоев, которые относятся также к нижнему кембрию.

Во всех изученных разрезах (рис. 1) четко выделяются люкатиские слои, представленные серовдто-зелеными алевритовыми глинами, содержащими тонкие прослойки и линзы мелкозернистого алевролита (рис. 2). В них найдены многочисленные Volborthella tenuis Schm. и песчаные фораминиферы. Кроме того, в скв. Калана встречены единичная находка

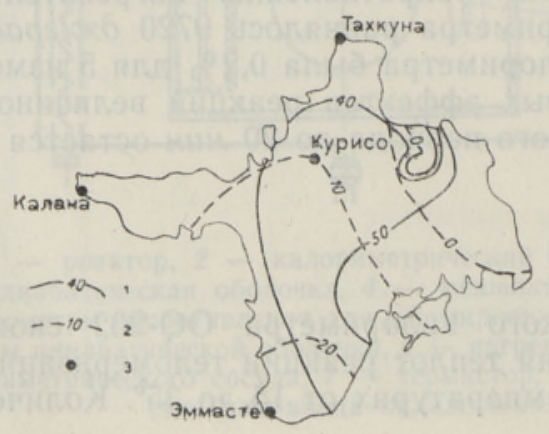

Paterina sp. и ходы Monocraterion. Мощность люкатиских слоев в изученных скважинах небольшая 2,3-6,2 м; к западу она уменьшается.

Рис. 1. Схема расположения изученных скважин и распределения мощностей отложений.

1 - изопахиты тискреских слоев; 2 изопахиты курземских слоев; 3 - буровые скважины, 
Над люкатискими слоями залегают тискреские слои (в объеме «тискреского горизонта» по Мардла и др., 1968), представленные желтоватосерыми слабосцементироваными крупнозернистыми кварцевыми алевролитами и алевритовыми песчаниками, содержащими в нижней своей части прослойки серовато-зеленых алевритовых глин. Суммарная мощность их составляет $30-50 \mu$ (рис. 2). В скв. Эммасте, по которой из интервалов со слабосцементированными песчаниками получен наибольший выход керна, наблюдается цикличное строение нижней части тискре. ских слоев, которые дватри раза чередуются, начинаясь внизу песчаниками или алевролитами и заканчиваясь вверху глинами.

Остатки фауны в данных слоях очень редки. В нижней части разрезов Эммасте и Тахкуна встречен черный детрит (по створкам Mickwitzia ?), а в последнем разрезе единичная створка Paterina sp. (гл. 94,0 м).

На тискреских слоях залегают синевато-серые алевритовые глины мощностью $1-11 \mu$, содержащие тонкие прослойки мелкозернистого песчаника и крупнозернистого алевролита, а в западной (скв. Калана) и южной (скв. Эммасте) частях о. Хийумаа прослойки (мощностью $0,1-0,3$ м) оолитового железняка фиолетово-коричневого цвета (рис. 2). Оолиты бурые, мелкие $\quad(0,2-0,3$ мм $)$, округлые, с концентрическим внутренним строением. Часть оолитов содержит ядро из кварца или других минералов (глауконита, циркона). Оолиты составляют в прослойках
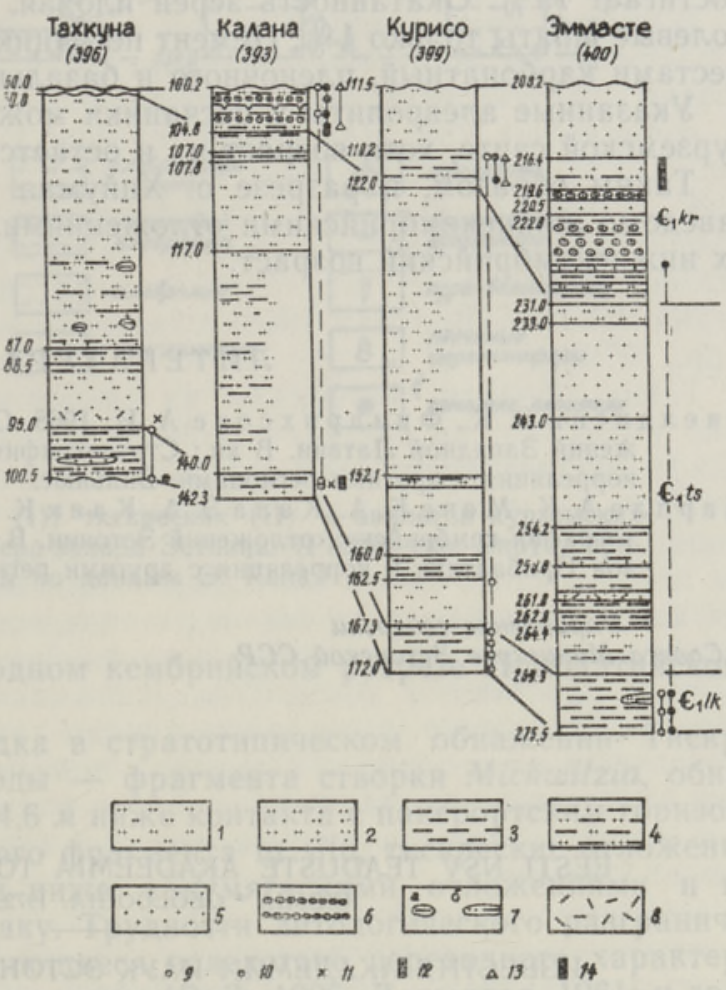

Рис. 2. Колонки верхней, изученной части кембрийских отложений о. Хийумаа.

1 - алевролит; 2 - песчанистый алевролит; 3 глина; 4 - алевритовая глина; 5 - кварцевый песчаник; 6 - оолитовый железняк; 7 - гальки и линзы из глины $(a)$ или глинистого алевролита (б); 8 - детрит брахиопод; 9 - Volborthella tenuis; 10 - песчаные фораминиферы; 11 - Paterina sp.; 12 - Monocraterion sp.; 13 - Serpulites sp.; $14-$ комплекс раннекембрийских акритарх: $1 \mathrm{k}$ - люкатиские, ts - тискреские; $\mathrm{kr}$ - курземские слои.

В интервалах, по которым керн представлен шламом, литология показана только в левой стороне колонки. $60-90 \%$ алевритовой породы.

В оолитовой глине из скважин Калана, Курисо и Эммасте найдены Volborthella tenuis Schm., песчаные фораминиферы и Serpulites sp. B скв. Эммасте с глубины 219,6-216,4 м Н. Умновой определены характерные нижнекембрийские акритархи Tasmanites bobrowskii Wasch., Leiopsophosphaera minutissima Umn., Trachypsophosphaera minutissima Umn., Granomarginata squamacea Volk., Microconcentrica atava Naum. 
По литологическому характеру и фаунистическому-флористическому составу указанные слои можно отнести к курз́емской свите, первоначально выделенной на территории Латвийской ССР (Лилдиена, Фридрихсоне, 1968).

Вверх по разрезу в скважинах Курисо и Эммасте на алевритовых глинах залегают еще желтовато-белые мелкозернистые кварцевые песчаники и крупнозернистые песчаные алевролиты мощностью $7-8$ м. Эти песчаники хорошо отсортированы; содержание фракции $0,1-0,25$ м. достигает $79 \%$. Окатанность зерен плохая. Кварц составляет $65-98 \%$, полевые шпаты только $1 \%$. Цемент песчаников гидрогетитово-глинистый, местами карбонатный, пленочного и базального типов.

Указанные алевролиты и песчаники можно условно отнести также к курземской свите, хотя возраст их и остается неизвестным.

Таким образом, в разрезе о. Хийумаа тискреские слои перекрыты заведомо нижнекембрийскими отложениями, что однозначно определяет их нижнекембрийский возраст.

\section{ЛИТЕРАТ У Р А}

Л и елди ен а Э. К., Фрид рих соне А. И. 1968. О стратиграфии кембрийских отложений Западной Латвии. В кн.: Стратиграфия нижнего палеозоя Прибалтики и корреляция с другими регионами. Вильнюс.

М а рдл а А. К., М ен с К. А., К а л а Э. А., К аяк К. Ф., Э р и сал у Э. К. 1968. К стратиграфии кембрийских отложений Эстонии. В кн.: Стратиграфия нижнего палеозоя Прибалтики и корреляция с другими регионами. Вильнюс.

Управление геологии

Совета Министров Эстонской ССР
Поступила в редакцию 15/III 1972

EESTI NSV TEADUSTE AKADEEMIA TOIMETISED. 21. KOIDE KEEMIA * GEOLOOGIA. 1972, NR. 3

ИЗВЕСТИЯ АКАДЕМИИ НАУК ЭСТОНСКОИ ССР. ТОМ 21 ХИМИด * ГЕОЛОТИЯ. 1972, 쇼 3

КАИСА МЕНС, Э. ПИРРУС

\section{НОВЫЕ ДАННЫЕ О ВОЗРАСТЕ ТИСКРЕСКИХ СЛОЕВ ПО МАТЕРИАЛАМ СЕВЕРО-ЗАПАДНЫХ РАЗРЕЗОВ ЭСТОНИИ}

KAISA MENS, E. PIRRUS, UUSI ANDMEID TISKRE KIHTIDE VANUSE KOHTA LOODE-EESTI LABILOIGETE ALUSEL

KAISA MENS, E. PIRRUS. NEW DATA ON THE AGE OF TISKRE BEDS IN THE NW OF ESTONIA

Результаты исследований кембрийских отложений в северных и западных районах Әстонии позволяют привести новые данные о возрасте тискреских слоев приглинтовой полосы и с большой достоверностью 